\title{
Diversity and distribution of Ludwigia (Onagraceae) in Paraíba State, Northeastern Brazil
}

\author{
Amanda Macêdo ROCHA ${ }^{1, *}$ \& José Iranildo Miranda de MELO ${ }^{2}$ \\ ${ }^{1}$ State University of Bahia, Department of Education, \\ Postgraduate Programme in Vegetal Biodiversity, HUNEB Herbarium (Collection Paulo Afonso), \\ Campus VIII, Rua do Gangorra, 503, Paulo Afonso, Bahia, CEP: 48600-000, Brazil. \\ ${ }^{2}$ State University of Paraíba, Biological Sciences and Health Center, Department of Biology, \\ Campina Grande, Paraíba, CEP: 58429-500, Brazil. \\ *Corresponding author: amandamacedorocha@gmail.com \\ 2Email: tournefort@gmail.com
}

\begin{abstract}
This paper provides a taxonomic assessment and distribution details of the species of the genus Ludwigia L. (Onagraceae) for the Paraíba State, Northeastern Brazil. Six species were found: L. erecta (L.) H.Hara, L. helminthorrhiza (Mart.) H.Hara, L. hyssopifolia (G.Don) Exell, L. leptocarpa (Nutt.) H.Hara, L. nervosa (Poir.) H.Hara and L. octovalvis (Jacq.) P.H.Raven. Ludwigia nervosa was recorded for the first time in the studied area. Our taxonomic treatment comprises an identification key to the species. For each species, description, illustrations, taxonomic comments, flowering and fruiting data, geographic distribution map, and the conservation status for the studied area are provided. Among the recorded species, three were classified as "Near Threatened", two as "Vulnerable" and one as "Critically Endangered".
\end{abstract}

Keywords. Conservation, Brazilian flora, Ludwigioideae, taxonomy.

Rocha A.C. \& Melo J.I.M. 2020. Diversity and distribution of Ludwigia (Onagraceae) in Paraíba State, Northeastern Brazil. European Journal of Taxonomy 639: 1-24. https://doi.org/10.5852/ejt.2020.639

\section{Introduction}

The flowering plant family Onagraceae Juss. includes approximately 660 species of herbs, shrubs, and trees in 22 genera and has a cosmopolitan distribution with prevalence in subtropical and temperate regions (Wagner et al. 2007). The family is particularly diverse in the New World, especially in western North America (Cabrera 1963; Levin et al. 2004), where various genera are distributed in different types of habitats. Representatives of the genus Ludwigia L. are typically found on humid or flooded sites, growing on the banks of lakes and rivers, with some species predominantly aquatic (Oziegbe et al. 2011).

Sixty-two species of Onagraceae have been recorded in Brazil, belonging to four genera: Epilobium L. (one species), Fuchsia L. (eight species), Ludwigia (45 species) and Oenothera L. (eight species). Among these species, 18 are endemic to Brazil, and the above-mentioned genera are mainly concentrated 
in the southern and southeastern regions, with exception of the genus Ludwigia, which is distributed throughout all geographic regions of the country (Vieira 2015).

Two subfamilies are recognized: Ludwigioideae W.L.Wagner \& Hoch, with the single tribe Jussiaeeae Dumort., which has a single genus (Ludwigia); and the large subfamily Onagroideae W.L.Wagner \& Hoch with six tribes: Circaeeae Dumort., Epilobieae Endl., Gongylocarpeae Donn.Sm. \& Rose, Hauyeae Raim. in Engl. \& Prantl, Lopezieae Spach and Onagreae Dumort., grouping all the other 21 genera (Wagner et al. 2007).

Among the genera of Onagraceae, Ludwigia can be recognized by the absence of the floral tube, pollen grains grouped in tetrads or polyads, sepals persistent after fertilization and following the ripening of the fruit, and nectariferous disk at the base of the stigma (Eyde 1978). These characteristics support the monophyly of the genus and indicate that Ludwigia represents the sister group to the remainder of Onagraceae (Wagner et al. 2007).

The first contribution to the taxonomy of Ludwigia in Brazil was published in the Flora Brasiliensis (Micheli 1872), with 37 species. Later, Munz (1947) presented a monograph on the Brazilian species of the genus, recognizing 33 species. Other taxonomical studies on the genus have been undertaken during the last decades, especially in southern and southeastern Brazil (Solomon \& Dietrich 1984; Grillo \& Giulietti 1998, 2004; Duarte \& Esteves 2001; Bertuzzi et al. 2011; Pesamosca \& Boldrini 2015). The diversity in other regions of Brazil, especially the Northeast, is less well documented. However, important researches have been undertaken in northeastern Brazil by Maciel \& Alves (2009), Melo et al . (2009), Pontes (2013) and Araújo et al. (2015).

Considering that information on the taxonomic diversity and distribution of Ludwigia (Onagraceae) is still scarce, especially in the Northeast Region of Brazil, this work presents a taxonomic study of Ludwigia in Paraíba State, Brazil, aiming at increasing our understanding of the diversity and distribution of the genus.

\section{Materials and methods}

\section{Study area}

The Paraíba State (Brazil) has a total area of $56468.435 \mathrm{~km}^{2}$ and lies in the easternmost region of the Brazilian Northeast, between $6^{\circ} 2^{\prime} 11.1^{\prime \prime}$ and $8^{\circ} 19^{\prime} 54.7^{\prime \prime} \mathrm{S}$, and between $34^{\circ} 45^{\prime} 50.4^{\prime \prime}$ and $38^{\circ} 47^{\prime} 58.3^{\prime \prime} \mathrm{W}$ (Fig. 1). Paraíba State comprises 223 municipalities and is divided into four mesoregions: Agreste, Borborema, Sertão and Mata (the coastal section) (AESA 2006).

There is a great diversity of climatic types in the Paraíba State: "As" (tropical climate, hot and humid, with rains in autumn and winter) predominates in the regions Coast, Brejo, Agreste and Sertão; "Bsh" (hot semi-arid climate) in the central region of the state and in the area of the Borborema Plain; "Aw" (hot and humid climate, with rains in summer-autumn); "Am" (monsoon climate), on the coastal region of the state (Francisco et al. 2015). Because Paraíba lies in the equatorial belt, there is a high solar incidence, featuring a hot climate with mean annual rainfall rates higher than $1600 \mathrm{~mm}$ and mean annual temperature between 21.5 and $26^{\circ} \mathrm{C}$, presenting scanty inter-annual oscillations and spatial distribution of temperature, which depends on land relief (AESA 2006; Francisco et al. 2015).

The greatly diversified land relief is characterized by depressions, plains, littoral plain and tablelands (AESA 2006). The vegetation cover varies with environmental and geomorphological conditions, featuring coastal vegetation (restinga), mangroves, savanna patches, humid forests, tablelands, hinterland woods, shrub woods (Caatinga) and hill forests (Carvalho \& Carvalho 1985). The predominant type of vegetation is Caatinga covering approximately $80 \%$ of the Paraíba State territory. 

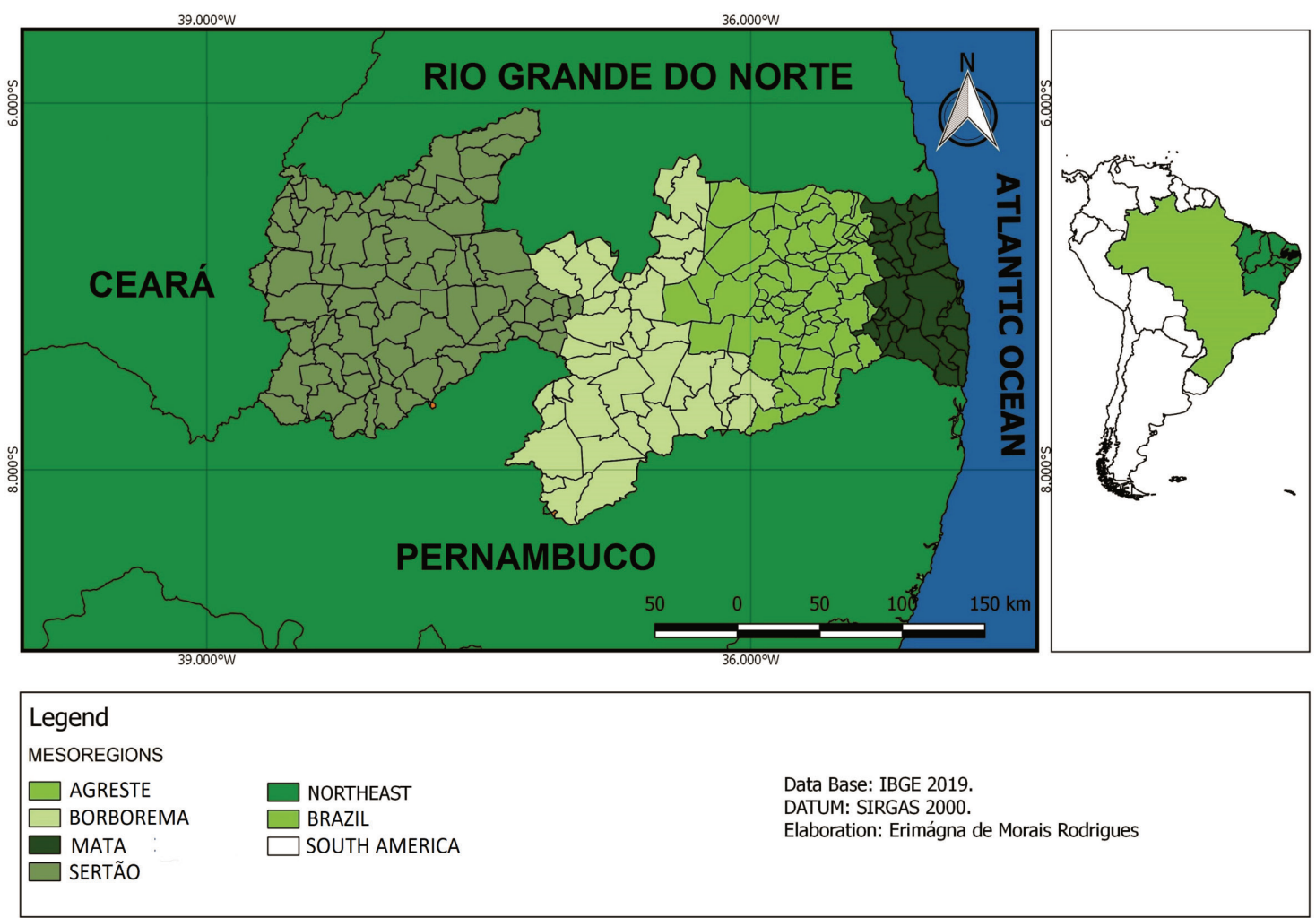

Fig. 1. Map of the study area, Paraíba State, northeastern Brazil. Maps by E. de Morais Rodrigues.

\section{Collection and processing of data}

Seventeen field trips through 38 municipalities within the four mesoregions were undertaken between July 2016 and November 2017. Samples of reproductive structures (flowers and fruits) were kept in $70 \%$ alcohol for the analysis of their structures. Photographs of the environments and species were taken, whilst relevant data, such as geographic coordinates and the characteristics of site and collected specimens, were registered in field. Specimens were dried following the methodology of Fidalgo \& Bononi (1984). The voucher specimens were deposited in the Herbarium Manuel de Arruda Câmara (HACAM) of the Universidade Estadual da Paraíba (UEPB), Campus I, duplicates were sent to the herbarium of HUNEB (Collection Paulo Afonso) of the Universidade do Estado da Bahia (UNEB).

Specimens belonging to the collections of the following herbaria in Paraíba were also analyzed: CSTR, EAN, and JPB, as well as specimens from the herbaria of the State of Pernambuco (IPA and PEUFR), Bahia (HUEFS) and Rio de Janeiro (RB). Databases of the Virtual Herbarium of Flora and Fungi (REFLORA, continuously updated) were also consulted.

\section{Repositories}

Herbarium acronyms follow Index Herbariorum (Thiers, continuously updated), except for the following repositories:

CSTR $=$ Herbarium Rita Baltazar de Lima, Patos, Paraíba State, Brazil

HACAM = Herbarium Manuel de Arruda Câmara, Campina Grande, Paraíba State, Brazil 
The identification of the material was based on Micheli (1872), Munz (1947), Raven (1963), Zardini \& Raven (1997), Goldblatt \& Raven (1997), Grillo \& Giulietti (1998, 2004) and Wagner et al. (2007). It was also based on the comparisons of specimens deposited at the visited herbaria. Protologues were obtained from the Biodiversity Heritage Library (BHL, continuously updated) website.

Morphological descriptions were prepared based on the analysis of material obtained during field trips, supplemented by specimens from the above-mentioned institutions. Descriptive terminology of vegetative and reproductive structures followed studies of the family Onagraceae as well as the works of Radford et al. (1974) and Harris \& Harris (2001). Additionally, we consulted the works of Rizzini (1977) for leaf typifying and Payne (1978) for indumentum. Abbreviations of names of the authors follow The International Plant Names Index (IPNI, continuously updated).

\section{Abbreviations}

$$
\begin{aligned}
\text { bud } & =\text { flower bud } \\
\text { fl. } & =\text { flower } \\
\text { fr. } & =\text { fruit } \\
\text { s.d. } & =\text { no date } \\
\text { s.n. } & =\text { no collection number }
\end{aligned}
$$

\section{Brazilian States}

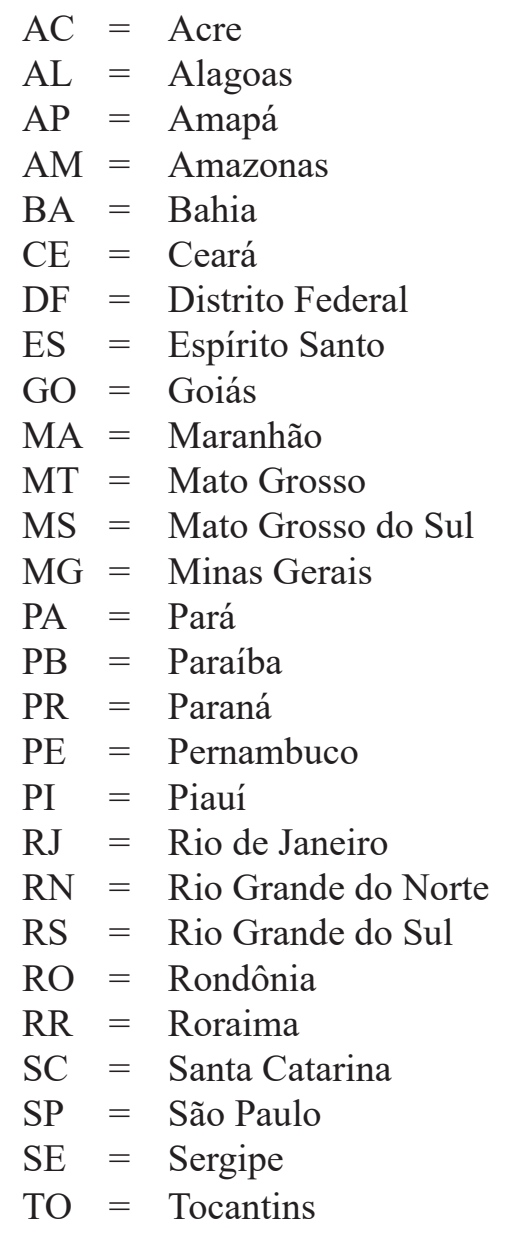

Data on the species geographic distribution were retrieved from specialized literature and from labels on the material examined in the herbaria. Data on habitats, flowering and fructification are taken from the labels of the studied material. 
Table 1. Species of Ludwigia L. (Onagraceae) in the Paraíba State, Brazil.

\begin{tabular}{lcccc}
\hline Species & $\begin{array}{c}\text { Endemic } \\
\text { to Brazil }\end{array}$ & $\begin{array}{c}\text { Phytogeographic domain } \\
\text { in Paraíba State } \\
\text { Catinga }\end{array}$ & $\begin{array}{c}\text { Atlantic } \\
\text { Rainforest }\end{array}$ & $\begin{array}{c}\text { New occurrence } \\
\text { in Paraíba State }\end{array}$ \\
\hline Ludwigia erecta & no & $\mathrm{X}$ & $\mathrm{X}$ & \\
Ludwigia helminthorrhiza & no & $\mathrm{X}$ & $\mathrm{X}$ & \\
Ludwigia hyssopifolia & no & $\mathrm{X}$ & $\mathrm{X}$ & \\
Ludwigia leptocarpa & $\mathrm{no}$ & $\mathrm{X}$ & $\mathrm{X}$ & \\
Ludwigia nervosa & $\mathrm{no}$ & & $\mathrm{X}$ & $\mathrm{X}$ \\
Ludwigia octovalvis & $\mathrm{no}$ & $\mathrm{X}$ & $\mathrm{X}$ & \\
\hline
\end{tabular}

Conservation status was determined for each taxon at the local scale (Paraíba State, Brazil). Criteria and categories established by the International Union for Conservation of Nature (IUCN 2001) were followed.

The extent of occurrence (EOO) and area of occupancy (AOO) of each species was calculated using the software GeoCAT, available at http://geocat.kew.org/editor, based on distribution data retrieved from voucher labels and from the collections.

\section{Results}

Six species of the genus Ludwigia (Onagraceae) are confirmed in the Paraíba State. Each species belongs to a distinct section: L. erecta (Ludwigia sect. Pterocaulon Ramamoorthy), L. helminthorrhiza (Ludwigia sect. Jussiaea (L.) Hoch., W.L.Wagner \& P.H.Raven), L. hyssopifolia (Ludwigia sect. Fissendocarpa (Haines) P.H.Raven), L. leptocarpa (Ludwigia sect. Seminuda P.H.Raven), L. nervosa (Ludwigia sect. Myrtocarpus (Munz) H.Hara) and L. octovalvis (Ludwigia sect. Macrocarpon (Micheli) H.Hara).

Although no endemic taxon to Brazil was reported, the current study provided one new record of Ludwigia for the flora of the Paraíba State (L. nervosa (Poir.) H.Hara). Most species were reported from the Caatinga and Atlantic Rainforest domains, except for L. nervosa that showed a preferential distribution in the Atlantic Rainforest (Table 1).

The conservation assessments revealed that three species are threatened: Ludwigia hyssopifolia and L. leptocarpa are considered as "Vulnerable" (VU) and L. nervosa as "Critically Endangered" (CR). The other species are not included on the list of threatened species.

Class Magnoliopsida Brongn.

Order Myrtales Juss. ex Bercht. \& J.Presl

Family Onagraceae Juss.

\section{Genus Ludwigia L.}

\section{Description}

Herbs erect or prostrate, subshrubs to trees, terrestrial or aquatic plants; branches pubescent to glabrescent. Leaves alternate, generally sessile to subsessile; stipules generally lacking or reduced. Flowers solitary, axillary, pedicellate or sessile; bracteoles absent or conspicuous, normally 2, near the base of hypanthium; calyx 4-5-merous, dialysepalous, green or reddish, persistent; corolla 4-5-(6)-merous, dialypetalous, 
yellow or white, deciduous; androecium isostemonous or diplostemonous, disposed in two series, epipetalous shorter than the episepalous, stamens inserted at the base of the epigynous disk together with the petals; hypanthium not extended above the ovary, cylindrical or angular, 4-5-carpellar, 4-5-locular, ovaries numerous, placentation axial, stigma capitate, globose, slightly lobular, the number of lobules corresponds to the number of locules; nectariferous disk generally plain or convex, on the ovary, nectary depressed, covered with indumentum of white trichomes. Fruit a capsule. Seeds small, numerous, unior pluriseriate in each locule, free or embedded in endocarp, generally with inconspicuous raphe, in some sections it may be expanded and equal in size to the body of the seed, or rarely expanded and wing-shaped (Ludwigia sect. Arborescentes Zardini \& P.H.Raven).

\section{Distribution}

The genus Ludwigia is pantropical. It is the only genus of the subfamily Ludwigioideae, composed of 83 species grouped in 23 sections, considered the most distinct genus of Onagraceae. Ten sections are distributed in South America, five in Africa, three in North America, three in Asia and two are not restricted to any continent. Main diversity centers are South America and North America (Wagner et al. 2007; Pesamosca \& Boldrini 2015).

\section{Habitat}

Specimens of Ludwigia were mainly collected from humid, flooded and aquatic environments (Fig. 2).

\section{Note}

In Brazil, species vernacular names are 'cruz-de-malta' or 'pimenta-d'água'.

\section{Key to Ludwigia species recorded in the Paraíba State, Brazil}

1. Leaves petiolate, leaf blade orbicular; petals white with yellow spot at the base

L. helminthorrhiza (Mart.) H.Hara

- Leaves subsessile to sessile, leaf blade elliptical to lanceolate or oblong-lanceolate to lanceolatelinear; petals entirely yellow (golden yellow or pale)

2. Flowers pentamerous sometimes hexamerous; endocarp horseshoe-shaped

L. leptocarpa (Nutt.) H.Hara

- Flowers tetramerous; when present, endocarp is never horseshoe-shaped

3. Petals with emarginate apex; raphe inflated, with diameter equal in size to the body of the seed L. octovalvis (Jacq.) P.H.Raven

- Petals with acute or attenuate apex; raphe non-inflated, with diameter narrower than the body of the seed

4. Fruits cylindrical; seeds usually pluriseriate and not embedded in the upper part of capsule, and uniseriate and embedded in endocarp in the lower part of capsule

L. hyssopifolia (G.Don) Exell

- Fruits tetrangular; seeds all pluriseriate and not embedded in endocarp 5

5. Leaf blade chartaceous; high nectariferous disk; capsule obconic

L. nervosa (Poir.) H.Hara

- Leaf blade membranaceous; plain nectariferous disk; capsule oblongoid L. erecta (L.) H.Hara. 

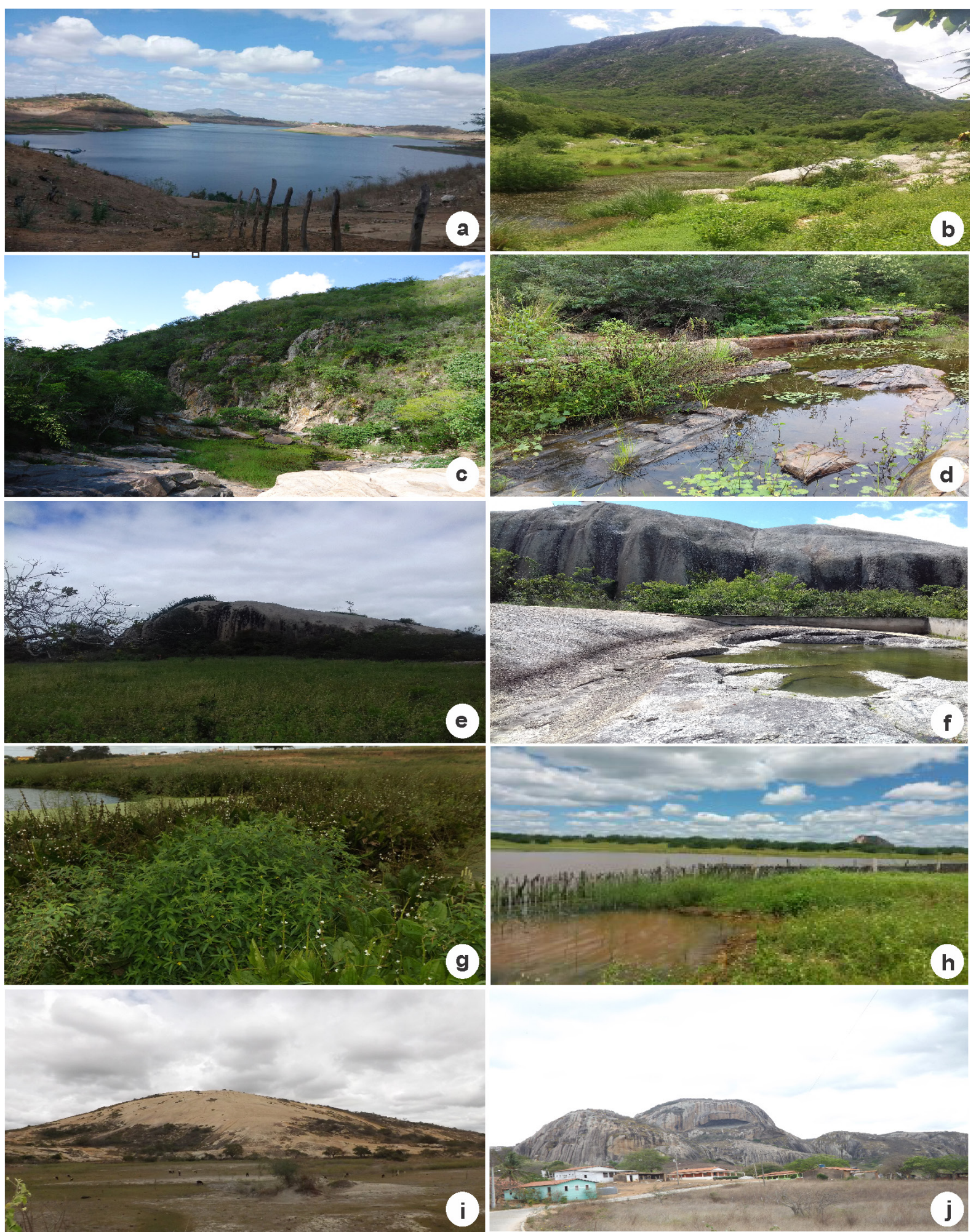

Fig. 2. Environments where species of Ludwigia L. were detected in the studied area, Paraíba State, Brazil. a. Açude Boqueirão, Boqueirão. b. Fazenda ABA, Passagem. c-d. Cachoeira do Pinga, Lagoa Seca. e-f. Afloramento granítico, Puxinanã. g. Monteito. h. Santa Luzia. i. Serra do Jatobá, Serra Branca. j. Parque Estadual Pedra da Boca, Araruna. Photos: $\mathrm{a}-\mathrm{h}=\mathrm{A} . \mathrm{M}$. Rocha, $\mathrm{i}-\mathrm{j}=$ F.K.S. Monteiro. 


\section{Ludwigia erecta (L.) H.Hara}

Figs $3 \mathrm{a}-\mathrm{j}, 4 \mathrm{a}-\mathrm{c}, 5 \mathrm{a}$

\section{Material examined}

BRAZIL - Paraíba - Alagoa Nova, Fazenda Roberto; 8 Mar. 2012; fr.; E. Melo 11062; HUEFS • Alagoinha, Estação Experimental; 10 Sep. 1942; Lauro Xavier s.n.; JPB[900] • Araruna; 19 Dec. 2016; fr.; A.M. Rocha 09; HACAM - Areia, Mata do Pau Ferro; 5 Oct. 1999; M.R. Barbosa 1841; JPB • Bananeiras, Cachoeira do Roncador; 15 Jan. 1998; fl. and fr.; C. Schlindwein 862; JPB - Boqueirão, Açude Epitácio Pessoa; 9 Apr. 2017; fl. and fr.; A.M. Rocha 15; HACAM • Cabaceiras, Lajedo de Pai Mateus; 3 May 2004; fl.; V.P.M. Coelho et al. 6278; JPB - Cajazeiras, bank of Açude de Lagoa de Arroz; 21 Dec. 2014; fr.; H.O. Machado-Filho 532; CSTR - Camalaú, Açude Camalaú; 15 Oct. 2013; H.O. Machado-Filho 176; JPB - Fagundes, Pedra de Santo Antônio; 29 Aug. 2005; S. Pitrez \& G. Trajano 639; EAN • Lagoa Seca, Cachoeira do Pinga; 11 Jul. 2017; fl. and fr.; A.M. Rocha 24; HACAM • Monte Horebe; 15 Mar. 2000; M.R. Barbosa et al. 2041; JPB • Monteiro; 27 Jun. 2017; fl.; A.M. Rocha 21; HACAM • Passagem, Fazenda ABA; 6 Apr. 2017; fl. and fr.; A.M. Rocha 13; HACAM - Patos, Açude São Bento; 7 Dec. 2016; fl. and fr.; A.M. Rocha 07; HACAM • Poço Dantas; 11 Oct. 2007; fl. and fr.; C.E.L. Lourenço et al. 285; JPB • Pombal; 1 Dec. 1955; José Carneiro s.n.; JPB[2902] - Puxinanã; 13 Jul. 2017; fl. and fr.; A.M. Rocha 26; HACAM • Remígio; 13 Sep. 2005; fl.; L.P. Felix 10800; EAN - Santa Luzia; 20 Apr. 2017; fl. and fr.; A.M. Rocha 17; HACAM - Santa Terezinha, RPPN Fazenda Tamanduá, inner forest, on the bank of a temporary river; 3 May 2011; fl.; D.S. Lucena et al. 111; CSTR • Sapé, margin of road PB-041; 1 Nov. 2017; fl.; A.M. Rocha 29; HACAM • Serra Branca, Serra do Jatobá; 21 Jul. 2016; fl. and fr.; A.M. Rocha 01; HACAM • Sossego; 4 Aug. 2008; fl.; S. G. Gerlandio 17; EAN • Sousa, Açude São Gonçalo; 15 Oct. 2013; fl.; H.O. Machado-Filho 196; PEUFR • Várzea, Cachoeira de São Pórfiro; 24 Aug. 2017; C.D. Ferreira et al. 36; CSTR.

\section{Description}

Herbs to subshrubs, 0.4-2 m high, erect; branches angular, scantily strigose. Leaves sessile; blade 7.1$11.2 \times 1.9-2.9 \mathrm{~cm}$, with entire margin, membranous, elliptical to lanceolate, apex acute, base decurrent, margins and veins of the dorsal face sparsely strigose. Flowers tetramerous, sessile; bracteoles 2, near the base of hypanthium, smaller than $1 \mathrm{~mm}$ in length.; sepals $4.2-4.5 \times 1.8-2 \mathrm{~mm}$, green, lanceolate, with acute apex, external face sparsely strigose; petals $5.1-5.5 \times 3.0-3.3 \mathrm{~mm}$, golden yellow, obovate, with rounded apex; hypanthium ca $8 \mathrm{~mm}$ in length, 4-locular; style ca $1 \mathrm{~mm}$ in length, stigma globose; stamens 8 , anthers globose; plain nectariferous disk with depressed nectaries, pilose, surrounding the base of each epipetalous stamen. Capsule 15-16 × 2-2.5 mm, oblongoid, 4-angled, internally not dimorphic, sparsely strigose. Seeds smaller than $1 \mathrm{~mm}$ in length, oblongoid, pluriseriate, not embedded in the endocarp, raphe non-inflated, with diameter narrower than the body of the seed.

\section{Distribution}

The species is widely distributed in Neotropical region, from Mexico and Florida (USA) to Brazil and Paraguay (Goldblatt \& Raven 1997). In Brazil, it occurs in the following regions and states: North (AM, AP, PA, RO), Northeast (AL, BA, CE, MA, PB, PE), Center-West (DF), Southeast (MG, RJ, SP) and South (PR), associated with Amazon, Caatinga, Savanna (Cerrado), Atlantic Rainforest and Pantanal phytogeographic domains (Vieira 2015).

\section{Habitat and phenology}

In Paraíba State the species may be found on the banks of lakes, dams, rivers, close to waterfalls or on humid sites, associated with Caatinga or the Atlantic Rainforest. Flowering and fructification occur between March and July and between December and January. 


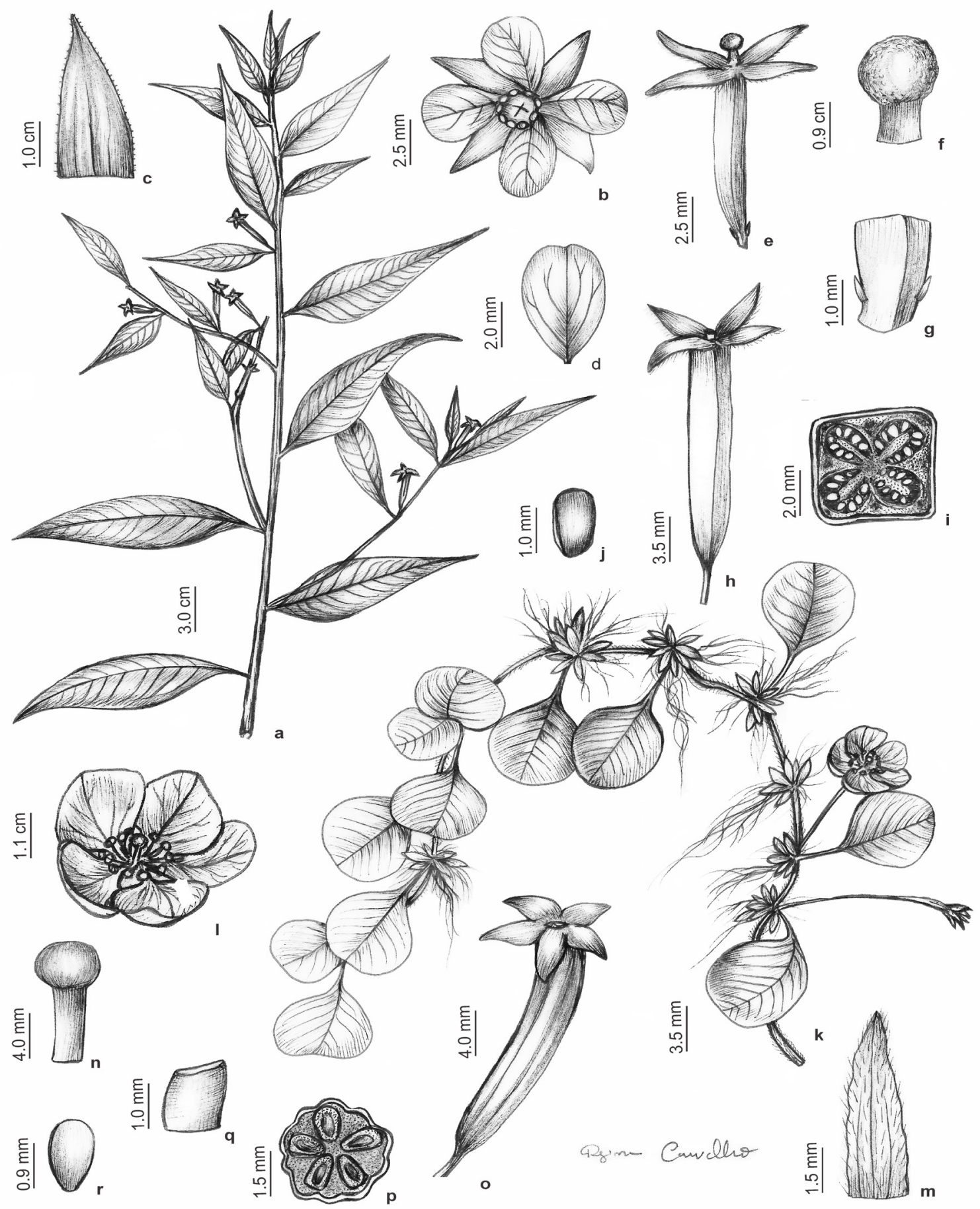

Fig. 3. a-j. Ludwigia erecta (L.) H.Hara, A.M. Rocha 26. a. Habit. b. Flower. c. Sepal. d. Petal. e. Gynoecium. f. Detail of stigma. g. Bracteoles. h. Fruit. i. Transversal cut of the fruit. j. Seed. k-r. L. helminthorrhiza (Mart.) H.Hara, A.M. Rocha and E.M. Rodrigues 27. k. Habit. I. Flower. m. Sepal. n. Detail of stigma. o. Fruit. p. Transversal cut of the fruit. q. Section of the endocarp. r. Seed. Illustrations by R.M.A. de Carvalho. 

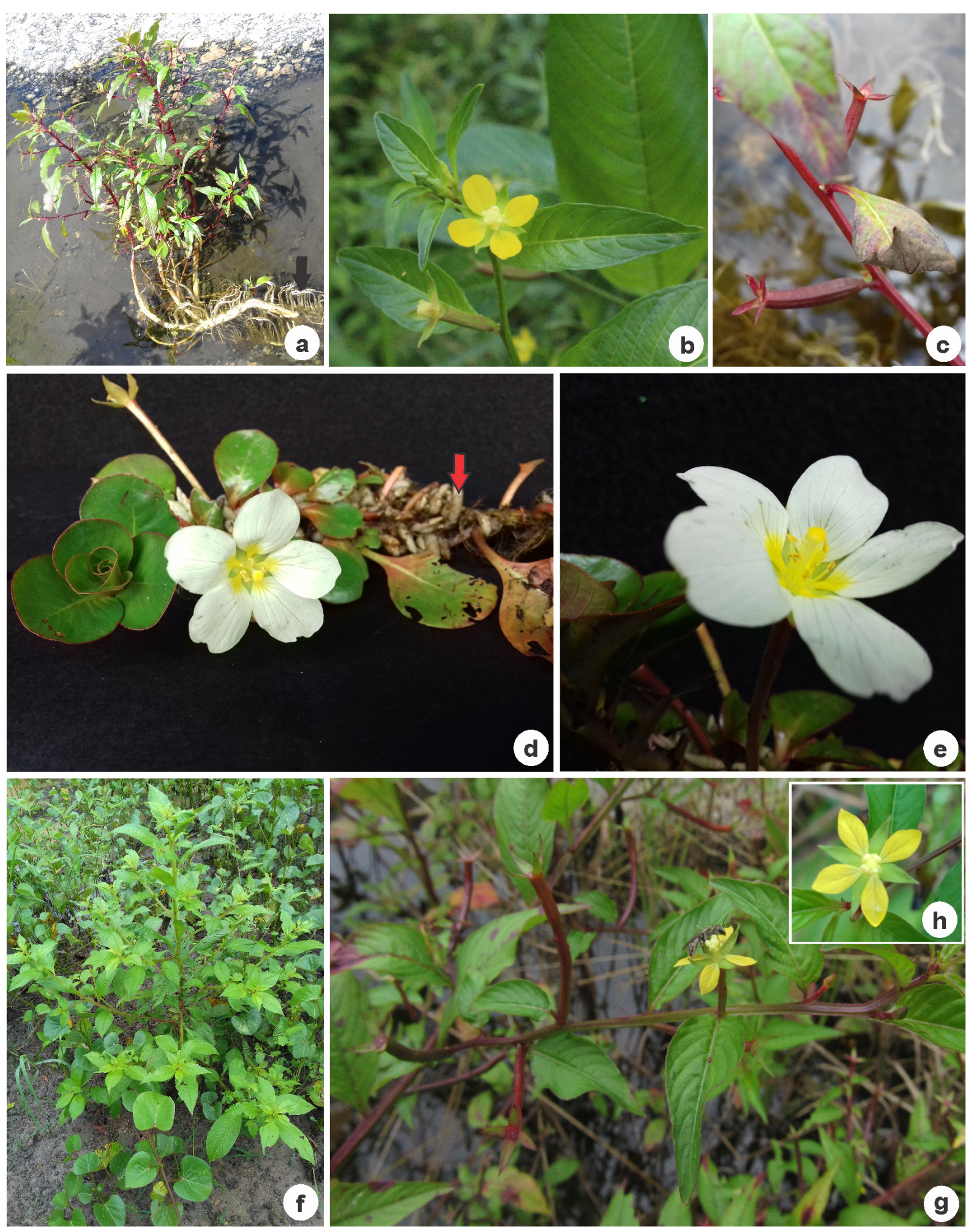

Fig. 4. a-c. Ludwigia erecta (L.) H.Hara. a. Habit showing pneumatophore roots (arrow). b. Flower. c. Fruits. - d-e. L. helminthorrhiza (Mart.) H.Hara. d. Habit showing spongy pneumatophore roots (arrow). e. Flower. $-\mathbf{f}-\mathbf{h}$. L. hyssopifolia (G.Don) Exell. f. Habit. g. Branch with flowers and fruits. h. Flower. Photos: a, $\mathrm{c}-\mathrm{f}=$ A.M. Rocha, b = F.C.P. Costa, g-h =H.C. Araújo. 
(a)

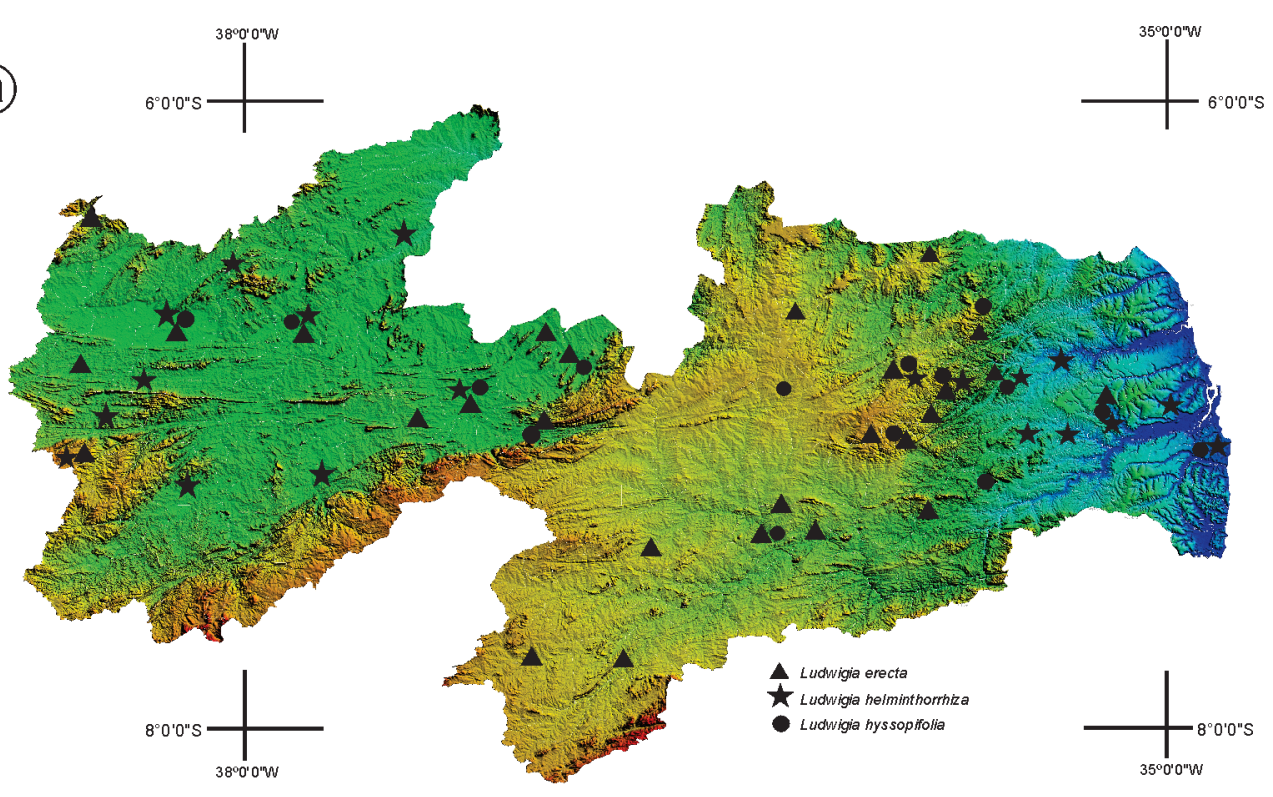

(b)

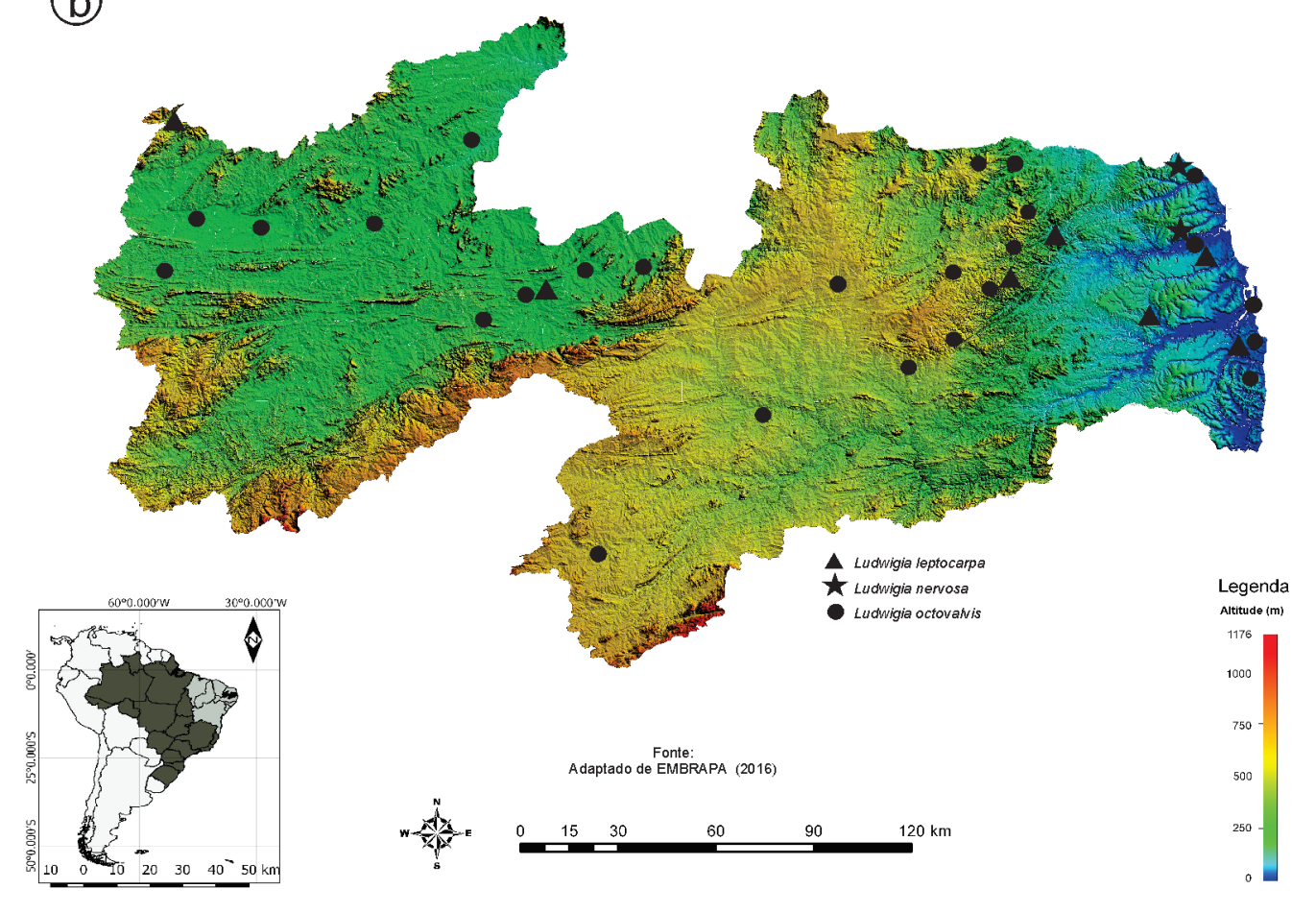

Fig. 5. Map showing the geographic distribution of Ludwigia L. species in the Paraíba State, Brazil. a. Ludwigia erecta (L.) H.Hara (৫), L. helminthorrhiza (Mart.) H.Hara ( $\star$ ), L. hyssopifolia (G.Don) Exell $(\bullet)$. b. L. leptocarpa (Nutt.) H.Hara (ム), L. nervosa (Poir.) H.Hara ( $\star$ ), L. octovalvis (Jacq.) P.H.Raven $(\bullet)$. Maps by E. de Morais Rodrigues. 


\section{Conservation status (Paraíba State, Brazil)}

The extent of occurrence (EOO) of Ludwigia erecta in the Paraíba State is $43308.511 \mathrm{~km}^{2}$, exceeding the upper limit for Vulnerable status under the criterion B1. The species has an area of occupancy (AOO) of $124 \mathrm{~km}^{2}$, within the limit for Endangered status under the criterion B2; however, L. erecta is recorded from more than 5 locations, 33 in the Paraíba State, and there is currently no evidence of a particular threat to its habitat, and no decline in the populations. Despite the AOO that suggests it is in Endangered category, L. erecta is evaluated as Near Threatened (NT), due to its wide distribution in Paraiba State.

\section{Note}

Ludwigia erecta is mainly distinguished by its oblongoid, tetrangular capsule and pluriseriate seeds, which are not embedded in the endocarp. The name of the section Ludwigia sect. Pterocaulon to which the species belongs refered to its four-angled stems and capsules (Ramamoorthy 1979).

\section{Ludwigia helminthorrhiza (Mart.) H.Hara}

Figs 3k-r, 4d-e, 5a

\section{Material examined}

BRAZIL - Paraíba • Alagoinha, Estação Experimental; 22 Sep. 1942; fl.; Lauro Xavier s.n.; JPB[958] - Araçagi, bank of the Açude Araçagi; 17 Mar. 2014; fr.; H.O. Machado-Filho 249; CSTR • Areia, Mata do Pau Ferro, near Açude Vaca Brava; 6 Oct. 1999; fl.; M.R. Barbosa 1864; JPB • Caldas Brandão, Cajá, temporary lake; 1 Nov. 2017; bud, fl. and fr.; A.M. Rocha \& E.M. Rodrigues 27; HACAM • Gurinhém; 23 Nov. 2015; I.C. Silva 10; IPA • Itaporanga, Fazenda Cafula; 24 Apr. 2010; M.K. Gomes 02; CSTR • João Pessoa, bank of the river Jaguaribe, Bairro Castelo Branco; 6 Jun. 2000; fl.; M. CostaSantos \& F.M. Barbosa 21; JPB - Monte Horebe, dam near the road to the municipality of Serra Grande; 24 Sep. 2014; fl. and fr.; J.L. Costa-Lima et al. 1873; RB - Nazarezinho, Rio Piranhas; 12 Oct. 2007; fl.; P.C. Gadelha-Neto 1901; JPB • Olho D’água; 22 Sep. 2015; T.A. Lycarião 34; IPA • Patos, Açude Jatobá; 10 Jul. 1997; R.L. Leite 23; JPB • Pombal, Sítio Maniçoba II; 28 Jul. 2011; fl.; P. D'Angelis et al. 101; CSTR • Remígio; 5 Oct. 2015; fl.; T.A. Lycarião 72; IPA • Santa Cruz, Fazenda Catolé; 30 Jul. 1983; M.A. Sousa 1301; JPB • Santa Rita; Jan. 1993; M.F. Agra 1917; JPB • São Bento, stream of Rio Piranhas; s.d.; R. Medeiros et al. 06; CSTR • São José de Piranhas, Reservoir Cuncas; 10 Jul. 2015; fl.; E. Araújo 45; RB • Sapé, Açude Salvador; 10 Jun. 2014; fl.; H.O. Machado-Filho 548; CSTR • Sousa, Vale dos Dinossauros; 10 Oct. 2007; P.C. Gadelha-Neto 1864; JPB.

\section{Description}

Herbs exclusively aquatic, decumbent; branches angular, floating, glabrous and hirsute, with white spongy pneumatophores emerging from each branch knot. Leaves petiolate; petiole 1.2-3.0 cm long; blade $4.4-5.7 \times 3.2-4.5 \mathrm{~cm}$, with entire margin, membranous, orbicular, with rounded apex and decurrent base, sharply narrow at the petiole, glabrous to sparsely strigose. Flowers pentamerous, pedicellate; pedicels ca $8.5 \mathrm{~cm}$ long; bracteoles not visible; sepals $6-8 \times 1.5-2 \mathrm{~mm}$, green, lanceolate, with acute apex, external face sparsely hirsute; petals $1.3-1.6 \times 1-1.1 \mathrm{~cm}$, white, with basal yellow spot, obovate, unguiculated, with rounded apex; hypanthium 9-12 mm long, 5-locular; style 4.5-5 mm long, stigma capitate; stamens 10, anthers oblong; plain nectariferous disk with depressed nectaries, pilose, surrounding the base of each epipetalous stamens. Capsule 21-27 × 3-4 mm, subcylindrical, 10-ribbed, gradually tapering at the base, not internally dimorphic, pubescent. Seeds ca $1.5 \mathrm{~mm}$ long, obovoid, uniseriate, firmly embedded in woody coherent endocarp, raphe non-inflated, with diameter narrower than the body of the seed. 


\section{Distribution}

Ludwigia helminthorrhiza is distributed in Central America, Argentina, Mexico, Paraguay, Peru and Venezuela; Africa and Madagascar (Campos 2010). In Brazil, it is restricted to the states of Bahia, Ceará, Pará, Paraíba and Mato Grosso do Sul, associated to phytogeographic domains of the Amazon, Caatinga and Pantanal (Vieira 2015; Torres et al. 2016).

\section{Habitat and phenology}

In the Paraíba State, it was collected in dams, temporary lakes, streams and rivers, linked to three mesoregions: Sertão, Agreste and Mata, associated with the Caatinga or Atlantic Rainforest. It produced flowers all the year round and fruits between June and July and between October and November.

\section{Conservation status (Paraíba State, Brazil)}

The extent of occurrence (EOO) of Ludwigia helminthorrhiza in the Paraíba State is $23582.060 \mathrm{~km}^{2}$, close to the upper limit for Vulnerable status under the criterion B1. Ludwigia helminthorrhiza has an area of occupancy (AOO) of $100 \mathrm{~km}^{2}$ which could qualify the species for the Endangered status under the criterion B2. However, L. helminthorrhiza is present at more than 5 locations and no evidence of threats or decline was observed. Ludwigia helminthorrhiza is assessed as Near Threatened (NT) in the Paraíba State.

\section{Note}

The species differs from other species of the genus in the studied area by its exclusively aquatic habit. Furthermore, it has spongy pneumatophore roots, orbicular leaves, white corolla with a yellow spot at the base and capsules with uniseriate seeds firmly embedded in woody coherent endocarp. Ludwigia helminthorrhiza belongs to Ludwigia sect. Jussiaea (= former section Oligospermum (Micheli) H.Hara), characterized by seeds strongly embedded in a portion of the woody endocarp (Zardini \& Raven 1992).

\section{Ludwigia hyssopifolia (G.Don) Exell}

Figs $4 \mathrm{f}-\mathrm{h}, 5 \mathrm{a}, 6 \mathrm{a}-\mathrm{k}$

\section{Material examined}

BRAZIL - Paraíba • Alagoinha, Estação Experimental; 24 Oct. 1942; Lauro Xavier s.n.; JPB[105] • Areia; Apr. 1992; fl.; M.P. Agra \& M.G. Silva 1829; JPB - Bananeiras, Goiamunduba Reserve; s.d.; fl. and fr.; E.C. Costa \& L.B.S. Pereira 203; HACAM - Cabaceiras; 26 Aug. 1982; fl.; P. Cascon \& J. Oliveira s.n.; JPB[17444] • Cruz do Espiríto Santo; 3 Nov. 1987; fl.; L.P. Felix \& E.C. Silva 1867; EAN - Ingá, Itacoatiara, microrregion of Piemonte da Borborema; 29 Apr. 1994; fl.; M.P. Agra \& E.A. Rocha 2857; JPB - João Pessoa, river Jaguaribe, close to Conjunto Castelo Branco; 13 Jul. 1982; fr.; O.T. Moura 215 A; JPB • Lagoa Seca, Cachoeira do Pinga; 11 Jul. 2017; fl.; A.M. Rocha 25; HACAM - Passagem, Fazenda ABA; 6 Apr. 2017; fl. and fr.; A.M. Rocha 14; HACAM • Patos, Várzea do Jurema; 29 Jul. 2011; C. Torres 98; CSTR • Pombal, Sítio Maniçoba II, bank of the Riacho dos Carneiros; 15 Jul. 2011; fl. and fr.; I.S. Queiroga 107; CSTR • Remígio; 23 Mar. 1975; fl.; V. Perazzo Barbosa 259; RB - Santa Luzia; 20 Apr. 2017; fl. and fr.; A.M. Rocha 16; HACAM • Sapé, Açude São Salvador; 10 Jun. 2014; fl. and fr.; H.O. Machado-Filho 549; CSTR - Sousa, Vale dos Dinossauros; 17 May 2005; bud; P.C. Gadelha-Neto 1379; JPB.

\section{Description}

Herbs to subshrubs, $0.4-0.87 \mathrm{~m}$ high, erect; branches angular, glabrous. Leaves sessile; blade $6.7-8 \times$ 2-2.5 cm, with entire margin, membranous, elliptic to lanceolate, with cuneate apex and decurrent base, glabrous. Flowers tetramerous, sessile; bracteoles 2, near the base of hypanthium, smaller than $1 \mathrm{~mm}$ in length; sepals 5-6 $\times 1.8-2 \mathrm{~mm}$, green, lanceolate, with acute apex, external and internal faces 


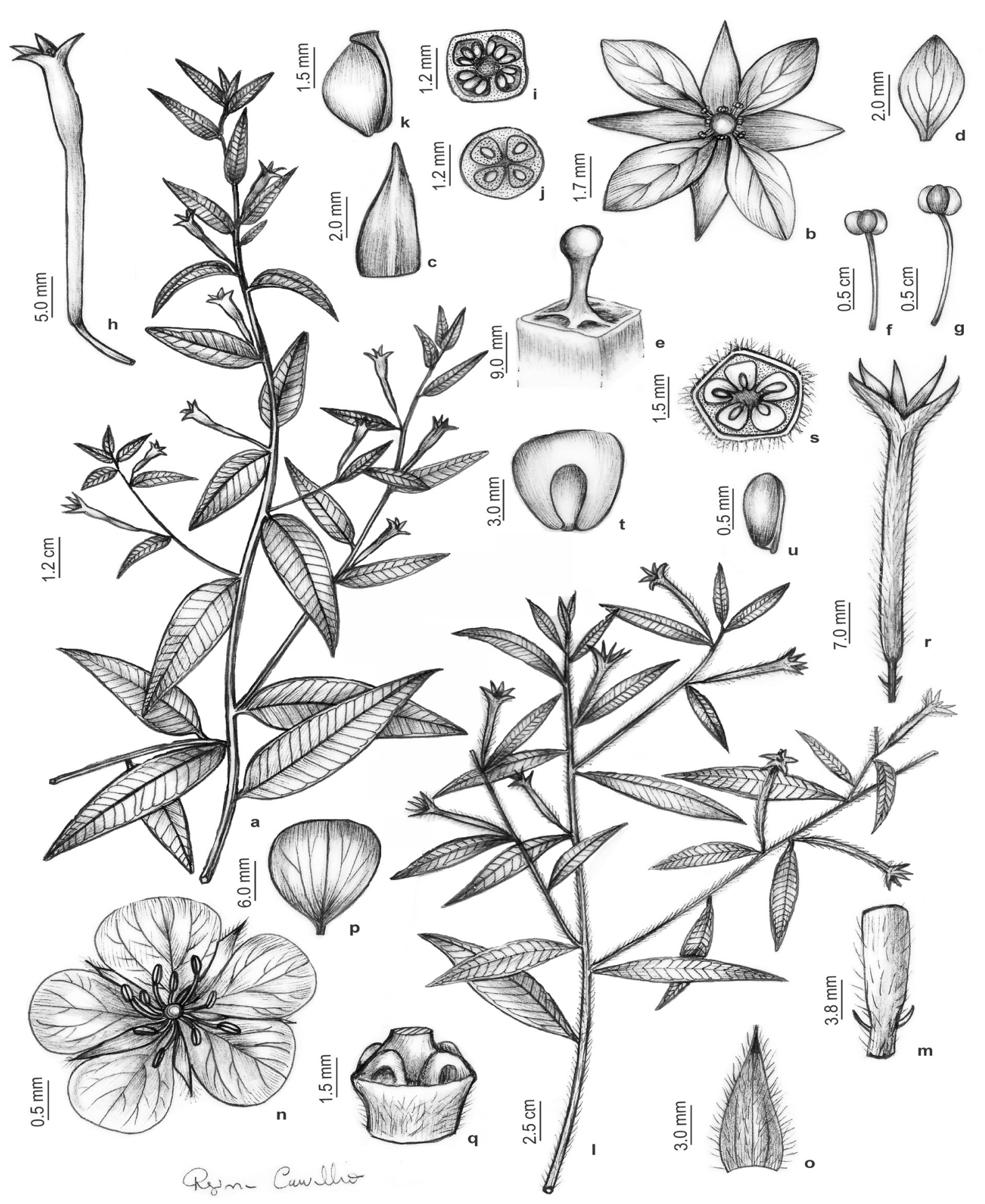

Fig. 6. a-k. Ludwigia hyssopifolia (G.Don) Exell, A.M. Rocha 16. a. Habit. b. Flower. c. Sepal. d. Petal. e. Plain nectariferous disk. f. Epipetalous stamen. g. Episepalous stamen. h. Fruit. i. Transversal cut of the upper section of the fruit. $\mathbf{j}$. Transversal cut of the lower section of the fruit. k. Seed. 1-u. L. leptocarpa (Nutt.) H.Hara, A.M. Rocha 06. I. Habit. m. Bracteoles. n. Flower. o. Sepal. p. Petal. q. Convex nectariferous disk. r. Fruit. s. Transversal cut of the fruit. t. Section of the horseshoe-shape endocarp. u. Seed. Illustrations by R.M.A. de Carvalho. 
glabrous; petals $4.5-5 \times 2.8-3 \mathrm{~mm}$, golden yellow, elliptic, with acute apex; hypanthium ca $8 \mathrm{~mm}$ long, 4-locular; style ca $2 \mathrm{~mm}$ long, stigma capitate; stamens 8 , anthers globose; plain nectariferous disk with depressed nectaries, pilose, surrounding the base of each epipetalous stamens. Capsule 25-27 $\times$ 1.5-2 mm, cylindrical, slightly wide at the distal region, internally dimorphic, glabrous. Seeds smaller than $1 \mathrm{~mm}$ in length, fusiform, pluriseriate and not embedded in endocarp in the upper part of the capsule, uniseriate and embedded in endocarp in the lower section of the capsule, raphe non-inflated, with diameter narrower than the body of the seed.

\section{Distribution}

Ludwigia hyssopifolia is a pantropical species (Raven 1963; Zardini \& Raven 1997). In Brazil, it is distributed in the North (AC, AM, PA, RO, RR), Northeast (AL, BA, PE), Central-West (MS, MT), Southeast (MG, SP) and South (PR) regions, associated with Amazon, Atlantic Rainforest and Pantanal phytogeographic domains (Vieira 2015).

\section{Habitat and phenology}

In the study area, L. hyssopifolia occurs from the Sertão region to the Mata region. It is found on humid soil, in swampy environments, or close to water courses, associated with the Caatinga and the Atlantic Rainforest. Flowers occur from January to October and fruits from May to September.

\section{Conservation status (Paraíba State, Brazil)}

The extent of occurrence (EOO) of Ludwigia hyssopifolia is $14285.685 \mathrm{~km}^{2}$, within the limit for the Vulnerable category (EOO less than $20000 \mathrm{~km}^{2}$ ). The species' area of occupancy (AOO) is $80 \mathrm{~km}^{2}$, within the limit for the Endangered category (criterion B2: less than $500 \mathrm{~km}^{2}$ ). However, L. hyssopifolia is recorded from more than 5 locations in the Paraíba State, and other conditions were not met to apply the criterion B2 (no evidence of populations fragmentation or decline, no threats or habitat loss). In the Paraíba State, the species falls under the category Vulnerable (VU), defined according to criterion B1ab(ii,iii) because only one record occurs in a conservation area, the Monumento Natural do Vale dos Dinossauros, in Sousa, the other locations where the species occurs are not protected areas and are affected by urban expansion.

\section{Note}

Most voucher specimens of L. hyssopifolia in the consulted herbaria are misidentified as L. erecta. The two species are similar, with tetramerous flowers with yellow petals, up to $5 \mathrm{~mm}$ long. However, the internaly dimorphic capsule with free pluriseriate seeds in the distal part and uniseriate seeds embedded in endocarp in the proximal part is the most important feature that distinguishes L. hyssopifolia from the others species. Dimorphism of the capsule characterizes Ludwigia sect. Fissendocarpa which is monospecific (Zardini \& Raven 1992; Wagner et al. 2007).

\section{Ludwigia leptocarpa (Nutt.) H.Hara \\ Figs $5 \mathrm{~b}, 61-\mathrm{u}, 7 \mathrm{a}-\mathrm{c}$}

\section{Material examined}

BRAZIL - Paraíba • Areia, UFPB; 2 Dec. 2016; fl.; A.M. Rocha 06; HACAM • João Pessoa, riparian vegetation of the Rio do Cabelo, Mangabeira; 19 Nov. 2010; fl.; L.A. Pereira 45; JPB - João Pessoa, AeroClube; 18 Nov. 2008; bud and fl.; A.C.C. Almeida 141; JPB - Patos, Assentamento Patativa do Assaré; 20 Jan. 2012; fl.; C. Torres 144; CSTR • Pirpirituba; 9 Sep. 2016; fl.; A.M. Rocha 03; HACAM - Poço Dantas; 11 Oct. 2007; fl.; G.A. Costa et al. 34; JPB • Rio Tinto, Gameleira; 6 Apr. 1989; fl.; L.P. Felix 3685; EAN・Sapé; 19 May 2014; fl.; H.O. Machado-Filho 426; PEUFR. 

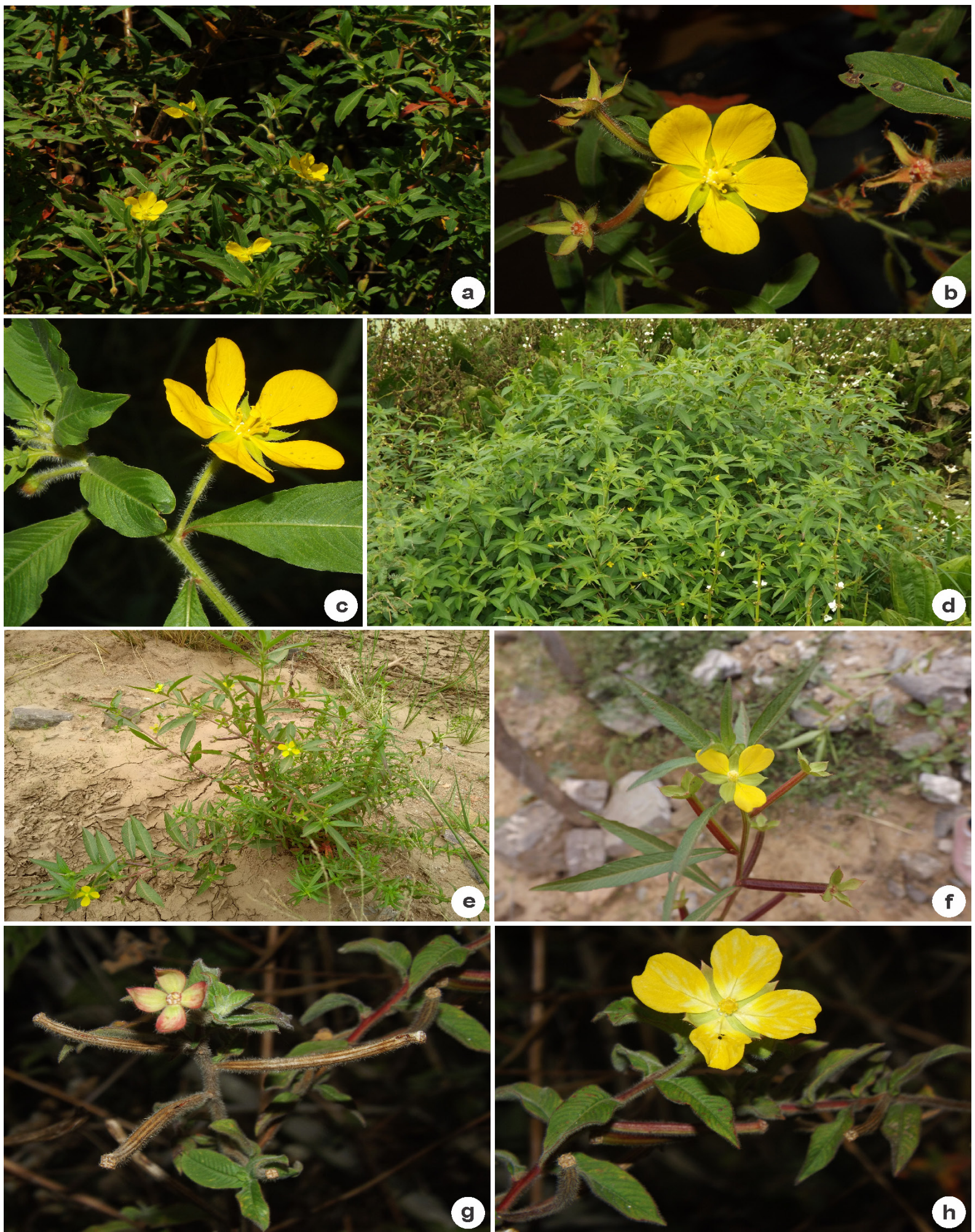

Fig. 7. a-c. Ludwigia leptocarpa (Nutt.) H.Hara. a. Habit. b. Flowering branch. c. Detail of indumentum. - d-h. L. octovalvis (Jacq.) P.H.Raven. d. Population. e. Habit. f-g. Flower. h. Fruits. Photos: A.M. Rocha. 


\section{Description}

Subshrubs, 1-1.6 m high, erect; branches cylindrical, hirsute. Leaves subsessile; blade 7-12.2 × $2.1-$ $2.6 \mathrm{~cm}$, with entire margin, membranous, elliptical, with acute apex and decurrent base, with hirsute nervure. Flowers pentamerous (sometimes hexamerous), pedicels ca $7 \mathrm{~mm}$ long.; bracteoles 2, near the base of hypanthium, smaller than $1 \mathrm{~mm}$ in length; sepals 10-11 $\times 3.5-4 \mathrm{~mm}$, green, lanceolate, with attenuate apex, external face hirsute; petals 15-16 × 12-13 mm, golden yellow, obovoid, shortunguiculated, with rounded apex; hypanthium ca $2 \mathrm{~cm}$ long, 5-locular; style ca $4 \mathrm{~mm}$ long, stigma capitate; stamens 10, anthers oblong; convex nectariferous disk with depressed nectaries, densely pilose, surrounding the base of each epipetalous stamens. Capsule $3.5-3.6 \times 2.6 \mathrm{~cm}$, cylindrical, internally nondimorphic, hirsute. Seeds ca $1 \mathrm{~mm}$ long, ellipsoid, uniseriate, embedded in horseshoe-shaped endocarp from which the seeds are easily detached, raphe non-inflated, with diameter narrower than the body of the seed.

\section{Distribution}

The species has a wide distribution in Neotropical region, from southeast USA to Argentina and Africa (Zardini \& Raven 1997). In Brazil, it occurs in almost all phytogeographic domains in North (AC, AM, PA), Northeast (AL, BA, CE, PB, PI, SE), Center-West (DF, GO, MS, MT), Southeast (ES, MG, RJ, SP) and South (PR, RS, SC) Region (Lima et al. 2013; Vieira 2015).

\section{Habitat and phenology}

In Paraíba State, L. leptocarpa may be found on the banks of lakes and in the flooded areas, in the vegetation of Caatinga and Atlantic Rainforest. It is flowering from September to December and fruiting in September.

\section{Conservation status (Paraíba State, Brazil)}

The extent of occurrence (EOO) of Ludwigia leptocarpa is $15683.720 \mathrm{~km}^{2}$ (within the limit for Vulnerable status under the criterion B1) and its area of occupancy (AOO) is $32 \mathrm{~km} 2$ (within the limit for Endangered status under the criterion B2). It is known from eight specimens representing a total of eight locations, within the threshold for Vulnerable under criterion B, no population has been recorded in a protected area. In the Paraíba State, the species falls under the category Vulnerable (VU), defined according to criterion B1 ab(ii,iii).

\section{Note}

Ludwigia leptocarpa is characterized by a yellow pentamerous corolla, which is a unique feature within the genus, as all other species of the genus have a tetramerous yellow corolla or a pentamerous white corolla. Uniseriate seeds embedded in horseshoe-shaped endocarp are the most relevant characteristic of L. leptocarpa. The horseshoe-shaped endocarp is a diagnostic feature of Ludwigia sect. Seminuda, a section to which L. leptocarpa belongs (Zardini \& Raven 1992; Wagner et al. 2007).

\section{Ludwigia nervosa (Poir.) H.Hara}

Figs $5 \mathrm{~b}, 8 \mathrm{~h}-\mathrm{n}$

\section{Material examined}

\section{Material from Paraíba State}

BRAZIL - Paraíba - Mataraca, between Camaratuba and the border with Rio Grande do Norte; 8 Feb. 1968; fl.; A. Lima 68-5312; IPA • Rio Tinto, Mata do Maracujá, Sema III; 23 May 1990; bud and fl.; L.P. Félix et al. 3023; EAN. 
Additional material examined

BRAZIL - Bahia • Belmonte, Barrolândia, Estação Experimental “Gregorio Bondar" CEPLAC; 13 May 1993; fl. and fr.; W. Thomas et al. s.n.; NY[9907].

\section{Description}

Shrubs, 2.5-3.5 m high, erect; branches cylindrical, glabrous to pilose. Leaves subsessile; blade 4.9$5.3 \times 0.9-1 \mathrm{~cm}$, with entire margin, chartaceous, lanceolate to oblong-lanceolate, with acute apex and acute to obtuse base, glabrous, with pubescent nervure. Flowers tetramerous, pedicellate; pedicels ca $1 \mathrm{~cm}$ long; bracteoles not visible; sepals $8-12 \times 4 \mathrm{~mm}$, green, lanceolate, with attenuate apex, external face sparsely pubescent; petals ca $14 \times 12 \mathrm{~mm}$, pale yellow, orbicular to obovoid, with rounded apex; hypanthium ca $1 \mathrm{~cm}$ long, 4-locular; style ca $2 \mathrm{~mm}$ long, stigma globose; stamens 8 , anthers linear; high nectariferous disk, ca $2 \mathrm{~mm}$ high, with depressed nectaries, densely pilose, surrounding the base of each epipetalous stamens. Capsule ca $13 \times 5 \mathrm{~mm}$, obconic, 4-angled, internally non-dimorphic, hirsute to glabrous. Seeds $1-1.5 \mathrm{~mm}$ long, oblongoid, transversally striated, pluriseriate, not embedded in endocarp, raphe non-inflated, narrower than the body of the seed.

\section{Distribution}

Ludwigia nervosa is distributed from South Mexico to Bolivia and Paraguay (Zardini \& Raven 1997). In Brazil, it is distributed in the North (AM, AP, PA, RO, RR, TO), Northeast (BA, MA, PE, PI), CenterWest (DF, GO, MS, MG), Southeast (ES, MG, RJ, SP) and South (PR) Region, in the phytogeographic domains of the Amazon, Atlantic Rainforest, Savanna (Cerrado), Caatinga and Pantanal (Vieira 2015).

\section{Habitat and phenology}

In the studied area, L. nervosa occurs only in the mesoregion Mata, in swampy environments, associated with Atlantic Rainforest vegetation. Flowers occur in February and May.

\section{Conservation status (Paraíba State, Brazil)}

The extent of occurrence (EOO) of Ludwigia nervosa is $0 \mathrm{~km}^{2}$ and its area of occupancy (AOO) is $8 \mathrm{~km}^{2}$. According to the IUCN criteria, the species is assessed as Critically Endangered (CR) under criterion B1ab(i,ii,iii)+2ab(i,ii,iii). Ludwigia nervosa is only known from 2 specimens in Paraíba State, one of which was collected almost 50 years ago, and the second 30 years ago. The biome with which it is associated in Paraíba State is frequently degraded by the expansion of sugarcane monocultures, posing a potential threat to the species and possibly causing a continuous decline of its population.

\section{Note}

Ludwigia nervosa differs from other Ludwigia species in the studied area by its chartaceous leaves, high nectariferous disk and obconic tetrangular capsule with pluriseriate seeds not embedded in endocarp. Seed characteristics were retrieved from Zardini \& Raven (1997).

\section{Ludwigia octovalvis (Jacq.) P.H.Raven}

Figs $5 \mathrm{~b}, 7 \mathrm{~d}-\mathrm{h}, 8 \mathrm{a}-\mathrm{g}$

\section{Material examined}

BRAZIL - Paraíba - Alagoa Nova, Fazenda Capim-Açú; 6 Mar. 2012; fl.; E. Melo et al. 10941; HUEFS • Araruna; 19 Dec. 2016; bud, fl. and fr.; A.M. Rocha 08; HACAM • Areia, Mata do Pau Ferro; 2 Dec. 2016; fl. and fr.; A.M. Rocha 05; HACAM - Bananeiras, Mata de Goiamunduba; Dec. 2012; fl.; E.C.S. Costa, L.B.S. Pereira \& J.I.M. Melo 202; HACAM • Cabedelo; 5 Apr. 1992; fl.; L.P. Felix et al. 4819; EAN • Cajazeiras, Açude Lagoa de Arroz; 21 Dec. 2013; H.O. Machado-Filho 536; IPA • Campina Grande, district Catolé; 8 Sep. 1989; fl.; I.C. Dantas s.n.; HACAM 332 • Conde, Rio Gramame; May 


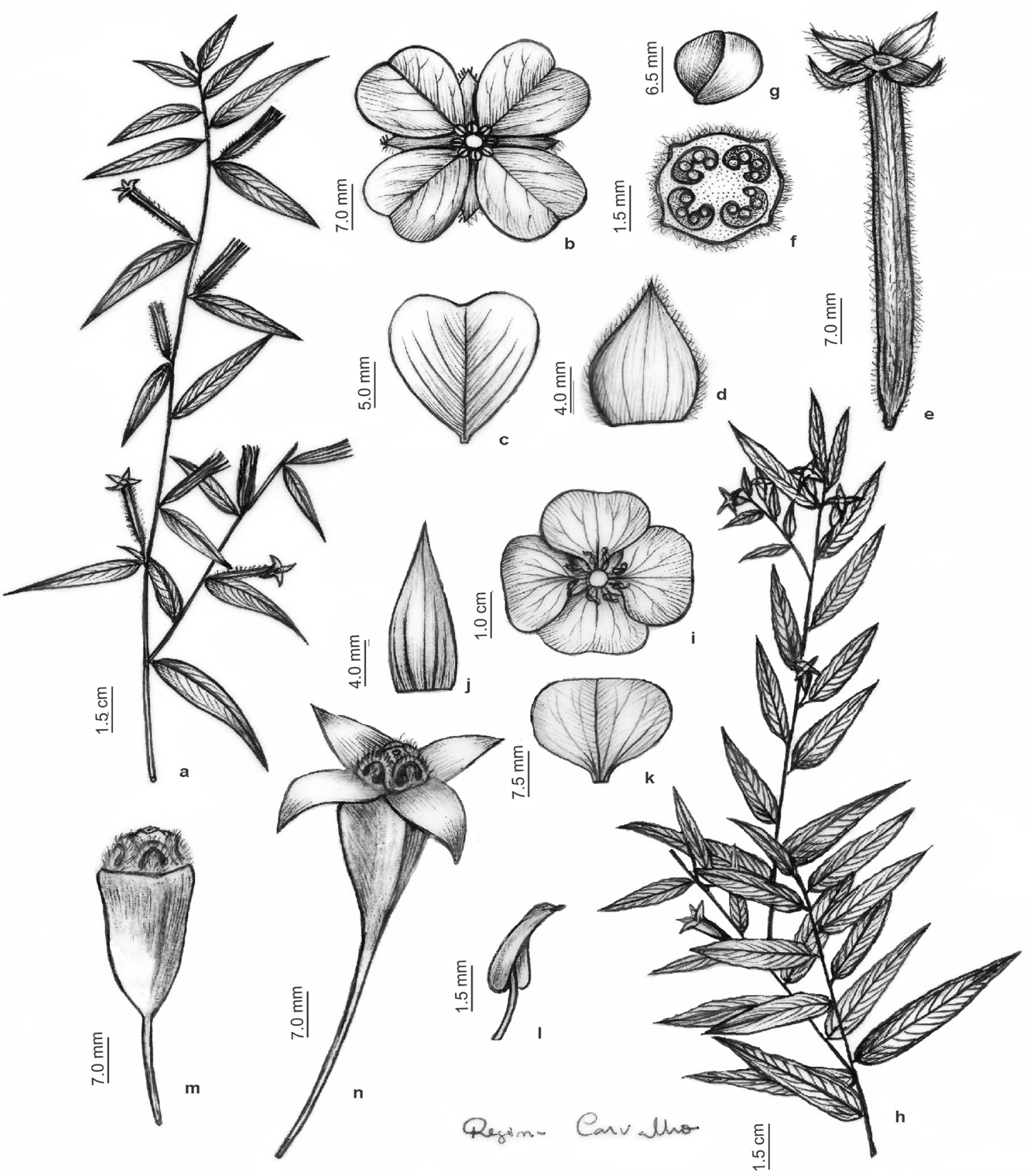

Fig. 8. a-g. Ludwigia octovalvis (Jacq.) P.H.Raven, A.M. Rocha 08. a. Habit. b. Flower. c. Sepal. d. Petal. e. Fruit. f. Transversal cut of the fruit. g. Seed. - h-n. L. nervosa (Poir.) H.Hara, L.P. Félix et al. 3023. h. Habit. i. Flower. j. Sepal. k. Petal. I. Stamen. m. Hypanthium with high nectariferous disk. n. Fruit. Illustrations by R.M.A. de Carvalho. 
2013; H.O. Machado-Filho s.n.; IPA[88439] - Cruz do Espírito Santo, Fazenda Massangana; 3 Nov. 1987; fl.; L.P. Felix \& E.C. Silva 1866; EAN • João Pessoa, riparian vegetation of the river Cuiá; 20 Jan. 2011; fl.; L.A. Pereira 135; JPB • Lagoa Seca, Pinga waterfall; 11 Jul. 2017; fl. and fr.; A.M. Rocha 23; HACAM • Mataraca; 1 Nov. 2017; bud, fl. and fr.; A.M. Rocha 28; HACAM • Monteiro; 27 Jun. 2017; fl. and fr.; A.M. Rocha 20; HACAM • Patos, Barragem da Farinha; 14 May 2012; C. Torres 299; CSTR - Pombal, Sítio Maniçoba II; 27 Mar. 2011; fl. and fr.; I.S. Queiroga 29; CSTR • Remígio; 19 Jul. 1972; fr.; V. Perazzo Barbosa 66; JPB • Riachão; 30 May 2001; fr.; M. Costa-Santos 60; JPB • Rio Tinto; 6 Apr. 1989; fl.; L.P. Felix 3569; EAN • Santa Luzia; 20 Apr. 2017; fl.; A.M. Rocha 18; HACAM • Santa Teresinha, Fazenda Tamanduá; 1 Mar. 2009; fr.; B. Laine \& J. Cortez 05; IPA • São Bento, Sítio Várzea da Serra, river Piranha; 17 Jan. 2015; F.G.Silva et al. 82; CSTR • São João do Cariri; 15 Jun. 2001; fl.; P.C. Gadelha-Neto et al. 639; JPB - São João do Rio do Peixe, Balneário de Brejo de Freiras; 31 Jul. 1974; fr.; L.P. Xavier s.n.; JPB[3593] - São Mamede, Fazenda Verdes Pastos; s.d.; fl. and fr.; R.C. Vila 04; CSTR • Serraria; 28 Nov. 1942; M.C. Espínola s.n.; JPB[1217] - Sousa, Fazenda Jangada; 25 Jun. 1995; fl.; P.C. Gadelha-Neto 221; JPB.

\section{Description}

Herbs to subshrubs, $0.3-1.65 \mathrm{~m}$ high, erect; branches cylindrical, subglabrous to pubescent. Leaves subsessile; blade 3.7-14.1 $\times 1.1-3.3 \mathrm{~cm}$, with entire margin, membranous, lanceolate-linear to oblonglanceolate, with acute apex and obtuse base, subglabrous to pubescent. Flowers tetramerous, sessile; bracteoles 2, near the base of hypanthium, less than $1 \mathrm{~mm}$ long; sepals $1.2-5 \times 67 \mathrm{~mm}$, green, ovate, with acute apex, external face hirsute to pubescent; petals 13-19 $\times 9-14 \mathrm{~mm}$, golden yellow, obovoid, with emarginate apex; hypanthium ca 2-2.7 cm long, 4-locular; style ca 1.5-2 mm long, stigma globose to ovoid; stamens 8, anthers globose; convex nectariferous disk with depressed nectaries, glabrous to densely pilose, surrounding the base of each epipetalous stamens. Capsule $3.5-57 \times 3.3-3.4 \mathrm{~mm}$, cylindrical, internally non-dimorphic, subglabrous to pubescent. Seeds less than $1 \mathrm{~mm}$ long, globoid, pluriseriate, not embedded in the endocarp, raphe inflated, equal in size to the body of the seed.

\section{Distribution}

Ludwigia octovalvis is widely distributed in tropical regions, although it is mainly found in the Americas (Raven 1963; Grillo \& Giulietti 2004). In Brazil, it occurs in the North (AC, AM, PA, RR, TO), Northeast (AL, BA, CE, MA, PB, PE, PI, RN, SE), Center-West (DF, GO, MS, MG), Southeast (ES, MG, RJ, $\mathrm{SP})$ and South (PR, SC) Region, associated with virtually all phytogeographic domains, excepting the Pampas domain (Vieira 2015).

\section{Habitat and phenology}

Ludwigia octotvalvis is well-distributed throughout the Paraíba State, associated with banks of dams and humid or prone to flooding sites. Flowers may be harvested throughout the year and fruits are collected in March, May, June and December.

\section{Conservation status (Paraíba State, Brazil)}

The extent of occurrence (EOO) of Ludwigia octovalvis in the Paraíba State is $44771.860 \mathrm{~km}^{2}$, exceeding the upper limit for Vulnerable status under the criterion B1. The species has an area of occupancy (AOO) of $120 \mathrm{~km}^{2}$, within the limit for Endangered status under the criterion B2. However, due to its EOO greater than $40000 \mathrm{~km}^{2}$, it does not fall within the threatened category. It is currently placed on the Near Threatened (NT) list.

\section{Note}

This species is mainly differentiated from other representatives of the genus in the study area by its seeds with inflated raphe with diameter equal to or greater than the body of the seed, a typical feature of 
Ludwigia sect. Macrocarpon (Zardini \& Raven 1992). Furthermore, it has petals with emarginated apex, 8-ribbed capsules, and pluriseriate seeds in the locule and not embedded in the endocarp.

According to Raven (1963), the species has a complex morphological variation. Specimens may be found varying in size, shape of leaf blades, density of branch and leaf indumentum, and in petal and fruit length (Duarte \& Esteves 2001). Precisely for this reason, Raven (1963) acknowledged two subspecies for South America: Ludwigia octovalvis subsp. octovalvis (Jacq.) P.H.Raven and Ludwigia octovalvis subsp. sessiliflora (Micheli) P.H.Raven. However, Raven \& Tai (1977) recognize only as a single species, since specimens of the two subspecies may be found on the same site. Thus, it is usual to find both populations with typical individuals and populations with individuals intermediate in morphological characteristics between the two subspecies. Differences are maintained by autogamy (Raven \& Tai 1977). In the study area, morphologically variable individuals were found. In this paper, the two distinct populations are treated as a single species, as suggested by Raven \& Tai (1977).

\section{Discussion}

The genus Ludwigia is the richest in number of species of the family Onagraceae. Currently, 45 species of the genus Ludwigia are recorded in Brazil, of which nineteen species (39.6\%) are endemic to the country (Vieira 2015), but only six species of the genus Ludwigia were found in the Paraíba State.

The identification of Ludwigia species is complex, mainly due to the fact that most of them have uniform characters, sharing pattern of stem architecture and leaf morphology. On the other hand, characters associated with leaves and indumentum can be widely variable under different environmental conditions, causing misinterpretations. Many species of the genus Ludwigia are amphibian and show phenotypic plasticity, with morphological features varying under different environmental conditions, causing complications in their identification (Dutartre et al. 2006).

In addition, there are other factors that make it even more difficult to identify Ludwigia species such as very easily detachable petals as well as autogamy detected in species (e.g., L. octovalvis), which may result in the establishment of intermediate individuals.

According to the literature, Ludwigia species are often associated with wetlands (Munz 1947; Oziegbe et al. 2011). In the study they were found occurring in rivers, streams, marshes, around ponds and weir as well as in water accumulated on rocky outcrops and in anthropized areas.

Characters most relevant for distinguishing of Ludwigia species recorded in the studied area were shape of the petals and fruits, arrangement of the ovules in locules, presence or absence of persistent endocarp tissue around the mature seeds, and last but not least, raphe size. Other researchers of the group also used some of these diagnostic features to separate species, as well as to delimitate distinct sections (e.g., Eyde 1978; Wagner et al. 2007). According to Eyde (1978) the most important distinguishing features in Ludwigia are the uniseriate or pluriseriate arrangement of the ovules and the presence or absence of persistent endocarp tissue around mature seeds; this author also found that seeds are embedded in endocarp only in taxa with uniseriate arrangement.

The present paper represents an important contribution to the knowledge of the Paraíba flora, especially for a better understanding of the delimitation of Ludwigia species, aiming to the development of future studies about the group beyond updating its geographical distribution in Paraíba state and northeastern Brazil. 


\section{Acknowledgements}

The first author would like to thank the Coordenação de Aperfeiçoamento de Pessoal de Nível Superior (CAPES) for the scholarship received. Thanks are also due to the Postgraduate Programme in Vegetal Biodiversity of the Universidade do Estado da Bahia (PPGBVeg-UNEB) for facilities in the undertaking of current research; to the Laboratory of Botany (LaBot) of the Universidade Estadual da Paraíba (UEPB) for its support in morpho-taxonomic analyses and to the Transport Sector and Postgraduate Programme in Ecology and Conservation of the Universidade Estadual da Paraíba (PPGEC-UEPB) for its support in all field trips in Paraíba. The authors would like to thank the curators of the visited herbaria for permission to examine the collections. To Regina Maria Alcântara de Carvalho for preparing the illustrations and Erimágna de Morais Rodrigues for the map of the studied area. J.I.M. Melo would like to thank the Conselho Nacional de Desenvolvimento Científico e Tecnológico (CNPq) for Scholarship in Research Productivity granted (PQ-2 Proc. n. 303867/2015-9).

\section{References}

AESA. 2006. Relatório final do Plano Estadual de recursos Hídricos: Agência Executiva de Gestão das Águas do Estado da Paraíba.

Available from http://www.aesa.pb.gov.br/aesa-website/documentos/plano-estadual/resumo-estendido/ [accessed 12 Oct. 2017].

Araújo C.B., Lima L.R. \&Vieira A.O.S. 2015. Onagraceae. In: Prata A.P.N., Farias M.C.V. \& Landim M.F. (eds) Flora de Sergipe: 203-211. Editora Criação, Aracaju.

Bertuzzi T., Grigoletto D., Canto-Dorow T.S. \& Eisinger S.M. 2011. O gênero Ludwigia L. (Onagraceae) no município de Santa Maria, Rio Grande do Sul, Brasil. Ciência e Natura 33: 43-73.

BHL. continuously updated. Biodiversity Heritage Library.

Available from https://www.biodiversitylibrary.org/ [accessed 26 Mar. 2020].

Cabrera A.L. 1963. Onagraceae. In: Cabrera A.L. (ed.) Flora de la Provincia de Buenos Aires. Vol. 4: 314-331. INTA, Buenos Aires.

Campos L.J.C. 2010. Clave para especies de Ludwigia L. (Onagraceae) de la región nor-oriental e insular de Venezuela depositadas en el herbario IRBR. Acta Botánica Venezuelica 33: 299-327.

Carvalho F.A.F. \& Carvalho M.G.F. 1985. Vegetação. In: Governo do Estado da Paraíba (ed.) Atlas Geográfico do Estado da Paraíba: 34-43. Secretaria da Educação/Ed. Grafset, João Pessoa.

Duarte M.C. \& Esteves G.L. 2001. Onagraceae. In: Melo M.M.R.F., Barros F., Chiea S.A.C., Kirizawa M., Jung-Mendaçolli S.L. \& Wanderley M.G.L. (eds) Flora Fanerogâmica da Ilha do Cardoso: 27-30. Instituto de Botânica, São Paulo.

Dutartre A., Haury J., Dandelot S., Coudreuse J., Ruaux B., Lambert E., Le Goffe P. \& Menozzi M.J. 2006. Les jussies: caractérisation des relations entre sites, populaçõess et activités humaines. Implications pour la gestion. In: Programme de Recherche "Invasions biologiques": 1-44. Cemagref, Bordeaux.

Eyde R.H. 1978. Reproductive structures and evolution in Ludwigia (Onagraceae). II. Fruit and seed. Annals of the Missouri Botanical Garden 65: 656-675. https://doi.org/10.2307/2398865

Fidalgo O. \& Bononi V.L.R. 1984. Técnica de Coleta, Preservação e Herborização de Material botânico. Instituto de Botânica, São Paulo.

Francisco P.R.M., Medeiros R.M., Santos D. \& Matos R.M. 2015. Classificação climática de Köppen e Thornthwaite para o Estado da Paraíba. Revista Brasileira de Geografia Física 8: 1006-1016. https://doi.org/10.5935/1984-2295.20150049

Goldblatt P. \& Raven P.H. 1997. Onagraceae. Bothalia 27: 149-165.

https://doi.org/10.4102/abc.v27i2.678 
Grillo A.A.S. \& Giulietti A.M. 1998. Flora da Serra do Cipó, Minas Gerais: Onagraceae. Boletim de Botânica da Universidade de São Paulo 17: 109-114.

https://doi.org/10.11606/issn.2316-9052.v17i0p109-114

Grillo A.A.S. \& Giulietti A.M. 2004. Flora de Grão-Mogol, Minas Gerais: Onagraceae. Boletim de Botânica da Universidade de São Paulo 22: 355-358.

https://doi.org/10.11606/issn.2316-9052.v22i2p355-358

Harris J.G. \& Harris M.W. 2001. Plant Identification Terminology: An Illustrated Glossary, Second Ed. Spring Lake Publishing, Spring Lake.

IPNI. continuously updated. The International Plant Names Index. Available from http://www.ipni.org [accessed 07 July 2019].

IUCN. 2001. IUCN Red List Categories and Criteria: Ver. 3.1. IUCN, Gland/Cambridge.

Levin R.A., Wagner W.L., Hoch P.C., Hahn W.J., Rodriguez A., Baum D.A., Katinas L., Zimmer E.A. \& Sytsma K.J. 2004. Paraphyly in tribe Onagreae: insights into phylogenetic relationships of Onagraceae based on nuclear and chloroplast sequence data. Systematic Botany 29: 147-164.

https://doi.org/10.1600/036364404772974293

Lima E.A., Oliveira Machado-Filho H. \& Melo J.I.M. 2013. Angiospermas aquáticas da Área de Proteção Ambiental (APA) do Cariri, Paraíba, Brasil. Rodriguésia 64: 667-683.

https://doi.org/10.1590/S2175-78602013000400001

Maciel J.R. \& Alves M. 2009. Onagraceae. In: Alves M., Araújo M.F., Maciel J.R. \& Martins S. (eds). Flora de Mirandiba: 273-274. Associação Plantas do Nordeste, Recife.

Melo J.I.M., Silva M.J. \& Sales M. F. 2009. Flora da região de Xingó, Alagoas e Sergipe: Onagraceae Juss. Sitientibus, Série Ciências biológicas 9: 106-109.

Micheli M. 1872. Onagraceae. In: Martius C.F.P., Eichler A.G. \& Urban I. (eds) Flora brasiliensis. Vol. 13, Part 2: 145-182. Frid. Fleischer, Leipzig.

Munz P.A. 1947. Onagraceae. In: Hoehne F.C. (ed.). Flora brasílica. Fasc. 9, Vol. 41: 1- 62. Secretaria da Agricultura, Indústria e Comércio de São Paulo, São Paulo.

Oziegbe M., Faluyi J.O. \& Azeez S.O. 2011. Comparative vegetative and fruit characteristics of seven Ludwigia Linn. species in Nigeria. Nigerian Journal of Botany 24: 219-230.

Payne W.W. 1978. A glossary of plant hair terminology. Brittonia 30: 239-255.

https://doi.org/10.2307/2806659

Pesamosca S.C. \& Boldrini I.I. 2015. Ludwigia litoranea (Onagraceae), a new species from coastal southern Brazil. Phytotaxa 230: 183-188. https://doi.org/10.11646/phytotaxa.230.2.5

Pontes T.A. 2013. Onagraceae. In: França F., Melo E., Souza I. \& Pugliesi L. (eds). Flora de Morro do Chapéu: 180-183. Universidade Estadual de Feira de Santana, Feira de Santana.

Radford A.E., Dickison W.C., Massey \& J.R. Bell C.R. 1974. Vascular Plant Systematics. Harper \& Row Publishers, New York.

Ramamoorthy T.P. 1979. A sectional revision of Ludwigia sect. Myrtocarpus sensu lato (Onagraceae). Annals of the Missouri Botanical Garden 66: 893-896. https://doi.org/10.2307/2398928

Raven P.H. \& Tai W. 1977. Observations of chromosomes in Ludwigia (Onagraceae). Annals of the Missouri Botanical Garden 66: 862-879. https://doi.org/10.2307/2398926

Raven P.H. 1963. The Old World Species of Ludwigia (including Jussiaea), with a Synopsis of the Genus (Onagraceae). Reinwardtia 6: 327-427. 
REFLORA. continuously updated. Virtual Herbarium of Flora and Fungi.

Available from http://reflora.jbrj.gov.br/reflora/herbarioVirtual/ [accessed 2 Jul. 2019].

Rizzini C.T. 1977. Sistematização terminológica da folha. Rodriguésia 42: 103-210.

Solomon J.C. \& Dietrich W. 1984. Onagraceae. In: Reitz P.R. (ed.). Flora Ilustrada Catarinense: 9-33. Herbário Barbosa Rodrigues, Itajaí.

Thiers B. continuously updated. Index Herbariorum: A global directory of public herbaria and associated staff. New York Botanical Garden's Virtual Herbarium.

Available from http://sweetgum.nybg.org/science/ih/ [accessed 12 July 2019].

Torres C.R.M., Fernando M.P. \& Lucena F.A. 2016. Checklist de plantas aquáticas em trechos de Caatinga do Semiárido paraibano, Nordeste do Brasil. Gaia Scientia 10: 284-296.

https://doi.org/10.21707/gs.v10.n04a23

Vieira A.O.S. Onagraceae. In: Lista de Espécies da Flora do Brasil. Jardim Botânico do Rio de Janeiro. Available from http://floradobrasil.jbrj.gov.br/jabot/floradobrasil/FB177 [accessed 02 July 2019].

Wagner L.W., Hoch P.C \& Raven P.H. 2007. Revised classification of the Onagraceae. Systematic Botany Monographs 83: 1-240.

Zardini E.M. \& Raven P.H. 1992. A new section of Ludwigia (Onagraceae) with a key to the sections of the genus. Systematic Botany 17: 481-485. https://doi.org/10.2307/2419486

Zardini E.M. \& Raven P.H. 1997. Onagraceae. In: Rizzo J.A. (ed.). Flora dos estados de Goiás e Tocantins: Coleção Rizzo. Vol. 20: 9-82. Editora da Universidade Federal de Goiás, Goiânia.

Manuscript received: 24 July 2019

Manuscript accepted: 23 January 2020

Published on: 4 May 2020

Topic editor: Frederik Leliaert

Desk editor: Radka Rosenbaumová

Printed versions of all papers are also deposited in the libraries of the institutes that are members of the EJT consortium: Muséum national d'histoire naturelle, Paris, France; Meise Botanic Garden, Belgium; Royal Museum for Central Africa, Tervuren, Belgium; Royal Belgian Institute of Natural Sciences, Brussels, Belgium; Natural History Museum of Denmark, Copenhagen, Denmark; Naturalis Biodiversity Center, Leiden, the Netherlands; Museo Nacional de Ciencias Naturales-CSIC, Madrid, Spain; Real Jardín Botánico de Madrid CSIC, Spain; Zoological Research Museum Alexander Koenig, Bonn, Germany; National Museum, Prague, Czech Republic. 